Venkataramann Sivsankar ${ }^{1}$, Thiagarajan Ramachandramoorthy ${ }^{2}$, M. Senthil Kumar ${ }^{3}$

\title{
DETERIORATION OF COASTAL GROUNDWATER QUALITY IN RAMESWARAM ISLAND OF RAMANATHAPURAM DISTRICT, SOUTHERN INDIA
}

\begin{abstract}
${ }^{1}$ Department of Chemistry, Thiagarajar College of Engineering, Tamil Nadu; ${ }^{2}$ PG \& Research Department of Chemistry, Bishop Heber College, Tamil Nadu; ${ }^{3}$ Department of Civil Engineering Sethu Institute of Technology, Tamil Nadu, India

A study was carried out in the South-West, North-East and North-West segments dividing the local area of Rameswaram Island to characterize the physico-chemical characteristics of 87 groundwater samples which include $p H$, electrical conductivity (EC), total dissolved solids (TDS), salinity, total alkalinity (TA), calcium hardness (CH), magnesium hardness, total hardness (TH), chloride and fluoride. heavy inorganic load in majority of the groundwater samples has been estimated due to the salinity, TDS, TH and chloride beyond the threshold level which substantiates the percolation of sea water into the freshwater confined zones. The Water Quality Index and Langeleir Saturation Index have also been calculated to know the potable and corrosive/incrusting nature of the water samples. The results are interpreted based on statistical tools. Greater than $80 \%$ of the samples were found to have exceeded the limit of WHO drinking standard especially in TDS, CH, TA and chloride. The signature of salt-water intrusion is observed from the ratio of $\mathrm{Cl} \mathrm{CO}_{3}{ }^{2-}+\mathrm{HCO}_{3}^{-}$and TA/TH. A proper management plan to cater potable water to the immediate needs of the people is to be envisaged.
\end{abstract}

Key words: water quality, coastal area, seawater intrusion, Langeleir saturation index.

\section{Introduction}

According to the reports of UNICEF and World Health Organization (WHO), every year about 2 million people die from diarrhoeal diseases and much of the disease burden is caused by contaminated drinking water and inadequate sanitation (Kaufmann, 2007). Groundwater is highly valued because of certain properties not possessed by surface water (Goel, 2000). The unscientific and inefficient use of this vital resource (water) is contributing to its increasing scarcity and sharp deterioration in its quality (Romani, 2007). Presently several millions of people are affected by fluorosis caused by its

(C) VENKATARAMANN SIVSANKAR, THIAGARAJAN RAMACHANDRAMOORTHY, M. SENTHIL KUMAR, 2013 
excess amount greater than $1.5 \mathrm{mg} / \mathrm{L}$ in many States of India and many countries (Datta, 2007). Endemic fluorosis is related to the high concentration of fluoride in drinking water ( $\mathrm{Li}$ et al., 1994). In continuation to our previous work (Sivasankar and Ramachandramoorthy, 2008; Ramachandramoorthy et al., 2008), the present study is aimed at characterizing the physico-chemical profile of groundwater samples collected from the local sources of Rameswaram Island, where salinity of water in the confined aquifers causing permanent loss to the fresh water storage capacity in terms of quality (Eilers et al., 1997; Masoud and Koike, 2006; Ward et al., 2003; Pozdnyakova and Zhang, 1999) and quantity as well.

\section{Details of the study area}

As far as the Hindus are concerned, pilgrimage is an essential part of their life for worship of God by undertaking "sthala yathra". Rameswaram is one of the pilgrimages, serving the purpose of promoting National Integration by attracting a vast confluence of people from Kashmir to Kanyakumari and from Bengal to Mumbai and also from various foreign countries.

\section{Location and climate}

The Ramanathapuram District is divided into two municipalities which is further subdivided into 7 Taluks with 429 Panchayats which includes 400 revenue villages and 236 hamlet villages (Statistical Handbook, 2006). In the Ramanathapuram District, Rameswarm is located at $9^{\circ} 28^{\prime}$ North Latitudes and $79^{\circ} 3^{\prime}$ 'East Longitudes with an average elevation of $10 \mathrm{~m}$ above the MSL, covering an area of $61.8 \mathrm{sq}, \mathrm{km}$ and a population of about 38,000. This religious Island in a shape of conch is a Taluk with 1 firka, 2 Revenue villages and 31 Hamlet villages. The climate prevails with a minimum temperature of $25^{\circ} \mathrm{C}$ in winter and a maximum of $36^{\circ} \mathrm{C}$ in summer. The average rainfall is $813 \mathrm{~mm}$.

In Rameswaram Island, the fluvino-marine deposits include indurated sand and dune sands. The Aeolian deposits comprise red sands which are in the nature of ancient dunes and occur over a stretch of $8 \mathrm{~km}$ length and $3.2 \mathrm{~km}$ width, and lie concordant to the sea coast. These are separated by marshy deposits of black clays. The sands are underlain by calcareous sandstones.

The marine formation comprises coastal plain deposits of sand and clay in varied proportion. Marine calcareous hardpan occurs as low terraces and platforms, with admixture of quartz, limonite and garnet concentrations. There are vast stretches of saline and alkaline soils found in the coastal blocks. Rameswaram Island contains mainly sandy soil and large quantities of lime stone 
deposit. The potash content of soil is high in all the blocks. Gypsum, lime stone and magnesium are few chemical compounds that are noteworthy. There are vast stretches of saline and alkaline soils found in the coastal blocks.

\section{Methods of Investigation}

A total of 87 groundwater samples (50 in the South-West (SW) segment; 21 in the North-East (NE) segment 16 in the North West (NW)s segment) from different sites of local Rameswaram Island were collected in a pre cleaned one liter polythene bottles with necessary precautions (Brown et al., 1974) and characterized for various physico-chemical parameters namely $\mathrm{pH}$, electrical conductivity (EC), total dissolved solids (TDS), salinity, calcium hardness $(\mathrm{CH})$, magnesium hardness $(\mathrm{MH})$, total hardness $(\mathrm{TH})$, total alkalinity (TA), chloride and fluoride. Standard procedures (APHA, 2005) were adopted for the determination of the various water quality parameters in the study.

Langeleir Saturation Iindex (LSI). Langeleir Saturation Index (Langeleir, 1946) is a system for estimating or predicting the amount or degree of problems with lime scale, a particular water supply will cause. The LSI value usually lies between -3 and +3 . If the LSI is positive, then the water will deposit $\mathrm{CaCO}_{3}$; on the other hand, the negative LSI value makes the $\mathrm{CaCO}_{3}$ to dissolve in water. According to Langelier, the corrosive action of water is principally due to an excess of free $\mathrm{CO}_{2}$ and its interaction with calcium and magnesium carbonates. In the presence of carbon-dioxide, these salts are held in solution as bicarbonates and for any given concentration of calcium and magnesium there is a corresponding concentration of carbon dioxide to prevent the decomposition of these bicarbonates back into carbonates. Corrosion is accelerated by low $\mathrm{pH}$ values, so that in water of low alkalinity and high free carbon dioxide, the attack is much more rapid as compared to water which is high in alkalinity and is low in carbon dioxide content.

$$
\begin{gathered}
\mathrm{LSI}=\mathrm{pH}-\mathrm{pH}(\mathrm{s}) \\
\mathrm{pH}(\mathrm{s})=(9.3+\mathrm{a}+\mathrm{b})-(\mathrm{c}+\mathrm{d}), \\
\text { where } \mathrm{pH}=-\log \left[\mathrm{H}^{+}\right], \mathrm{a}=\log 10(\mathrm{TDS})-1 / 10, \mathrm{~b}=-13.12 \cdot \log 10\left(\mathrm{~T}^{\circ} \mathrm{C}+273\right)+ \\
34.55, \mathrm{c}=\log 10\left(\mathrm{Ca}^{2+} \text { as } \mathrm{CaCO}_{3}, \mathrm{mg} / \mathrm{L}\right)-0.4, \mathrm{~d}=\log 10 \\
\text { (alkalinity as } \left.\mathrm{CaCO}_{3}, \mathrm{mg} / \mathrm{L}\right)
\end{gathered}
$$


Water Quality Index (WQI). Water Quality Index (Tiwari, 1985) is a very useful and efficient tool for communicating the overall quality of water. To determine the suitability of the groundwater for drinking purposes, WQI is computed by adopting the method which is formulated as, WQI = Antilog$\left[\mathrm{SW}^{\mathrm{n}} \mathrm{n}=1 \log 10 \mathrm{qn}\right]$. Where Wn, Weightage $=\mathrm{K} / \mathrm{Sn}$ and $\mathrm{K}$, Constant $=$ $1 /\left(\mathrm{S}^{\mathrm{n}} \mathrm{n}=11 / \mathrm{Si}\right) \mathrm{Sn}$ and $\mathrm{Si}$ correspond to the WHO/ICMR standard value of the parameters. Quality rating $(\mathrm{q})$ is calculated as Qni $=\left[\left(\mathrm{V}_{\text {actual }}-\mathrm{V}_{\text {ideal }}\right) / \mathrm{V}_{\text {standard }}-\right.$ $\left.\left.\mathrm{V}_{\text {ideal }}\right)\right] \cdot 100$. Where Qni = quality rating of ith parameter for a total of 'n' water samples $\mathrm{V}_{\text {actual }}=$ Value of the water quality parameter obtained from the laboratory analysis. $V_{\text {standard }}=$ Value of the water quality parameter obtained from the standard tables. $\mathrm{V}_{\text {ideal }}$ for $\mathrm{pH}=7$ and for the other parameters it is equivalent to zero.

Statistical analysis. The data was processed by applying principal component analysis (PCA) in order to gain the knowledge on the distribution of pollutants by detecting similarities and differences between the data. The data arranged in a matrix with chemical parameters as columns and samples as rows. The PCA was carried out with factors having eigen vectors higher than one (Kaiser criterion). The principal components (PCs) are extracted in decreasing order of importance, so that the first PC accounts for as much of the variation as possible and each successive component accounts are little less. As the first PC accounts for the co-variation shared by all attributes, this may be a better estimate than simple or weighted averages of the original variables. The variables in descending order by absolute value of their loading co-efficient are obtained by sorted size option. Thus the loadings were grouped on the basis of highest load highest. During the PCA the loadings were suppressed to less than 0.1 in absolute value, and thus small values are replaced with blanks. The quality of data for factor analysis is confirmed with Kaiser-Meyer-Olkin (KMO) test. Afterwards, the rotation of PCs was made by varimax-normalised algorithm, which allows simplifying interpretation by maximizing the variance (Kaiser, 1958) of the variable loadings on each factor. High loadings on single factors are obtained by varimax rotation. The PC loading of different segments of the study area were analysed and box plots are drawn for each physico-chemical parameter.

\section{Results and discussion}

During the study period the groundwater samples were analyzed for different water quality parameters. The data interpretation is made by correlation matrix and PCA. The descriptive statistics of the studied groundwater samples in the SW, NE and NW segments of local Rameswaram area is also shown in Table 1. The $\mathrm{pH}$ of the groundwater samples in the study area observed from neutral to alkaline nature, recorded with the mean $\mathrm{pH}$ values of 7.39, 7.38 and 7.57 in the SW, NW and NE segments respectively. 


\begin{tabular}{|c|c|c|c|c|c|c|c|c|c|c|c|}
\hline \multirow{3}{*}{ 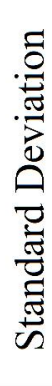 } & $\bar{Z}$ & $\underset{0}{\vec{\sigma}}$ & $\underset{\substack{+\sim}}{+}$ & $\begin{array}{l}\tilde{b} \\
\stackrel{\sim}{n} \\
n\end{array}$ & $\stackrel{\circ}{\circ}$ & 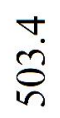 & $\stackrel{\stackrel{\Xi}{ \pm}}{=}$ & $\hat{\theta}$ & $\begin{array}{l}\infty \\
\infty \\
\infty \\
n\end{array}$ & $\overrightarrow{\text { ते }}$ & $\stackrel{+}{n}$ \\
\hline & 之 & $\begin{array}{l}\infty \\
\stackrel{0}{o}\end{array}$ & $\begin{array}{l}\stackrel{+}{\infty} \\
\text { ¿ }\end{array}$ & 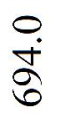 & $\stackrel{\stackrel{ }{d}}{\sim}$ & $\frac{?}{8}$ & $\begin{array}{l}\infty \\
\stackrel{\infty}{\sim} \\
\stackrel{2}{2}\end{array}$ & 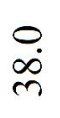 & $\stackrel{\curvearrowright}{\curvearrowright}$ & $\begin{array}{l}0 \\
\stackrel{0}{0} \\
\stackrel{0}{\sim}\end{array}$ & 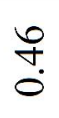 \\
\hline & 3 & $\stackrel{\overbrace ్}{0}$ & $\begin{array}{l}0 \\
\text { in } \\
\end{array}$ & $\frac{\nabla}{\dot{\theta}}$ & $\stackrel{\circ}{n}$ & 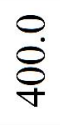 & $\vec{\infty}$ & $\stackrel{\infty}{2}$ & $\begin{array}{l}b \\
\dot{J} \\
\dot{I}\end{array}$ & $\begin{array}{l}0 \\
\infty \\
\infty \\
0\end{array}$ & $\stackrel{+}{\circ}$ \\
\hline \multirow{3}{*}{$\sum_{\Sigma}^{\mathbb{\Xi}}$} & $\mathrm{Z}$ & $\tilde{n}$ & $\begin{array}{l}\stackrel{0}{0} \\
\dot{\infty}\end{array}$ & $\begin{array}{l}\dot{0} \\
\stackrel{\dot{v}}{ \pm}\end{array}$ & $\begin{array}{l}\text { i⿱ } \\
\text { ñ }\end{array}$ & $\frac{g}{9}$ & $\frac{\vec{g}}{\vec{\gamma}}$ & $\begin{array}{l}\infty \\
\stackrel{\infty}{\sim} \\
i\end{array}$ & $\begin{array}{l}q \\
\tilde{\sigma} \\
\dot{q}\end{array}$ & \begin{tabular}{l}
$\stackrel{y}{y}$ \\
\multirow{y}{y}{}
\end{tabular} & $\begin{array}{l}\nabla \\
ٌ\end{array}$ \\
\hline & z & $\stackrel{\infty}{\stackrel{\infty}{r}}$ & $\begin{array}{l}\infty \\
\stackrel{\infty}{0} \\
\stackrel{n}{\sim}\end{array}$ & $\begin{array}{l}n \\
2 \\
\infty \\
0\end{array}$ & $\begin{array}{l}8 \\
\stackrel{8}{n} \\
\text { n. }\end{array}$ & $\begin{array}{l}n \\
\infty \\
\infty \\
\infty\end{array}$ & $\overrightarrow{0}$ & $\overrightarrow{\grave{d}}$ & $\frac{n}{n}$ & 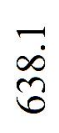 & $\begin{array}{l}\infty \\
\infty \\
\dot{0}\end{array}$ \\
\hline & in & ले & 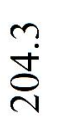 & $\begin{array}{l}\stackrel{0}{\dot{a}} \\
\stackrel{\partial}{ \pm}\end{array}$ & 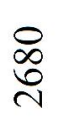 & $\begin{array}{l}\stackrel{0}{\dot{I}} \\
\underset{I}{ \pm}\end{array}$ & $\begin{array}{l}\stackrel{y}{+} \\
\dot{n} \\
\ddot{n}\end{array}$ & $\begin{array}{l}\bar{D} \\
\stackrel{\infty}{\sim}\end{array}$ & $\begin{array}{l}n \\
m \\
m\end{array}$ & 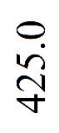 & $\stackrel{\circ}{n}$ \\
\hline \multirow{3}{*}{ 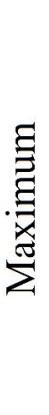 } & $\mathrm{I}$ & $\begin{array}{l}\infty \\
\cdots \\
\infty\end{array}$ & $\begin{array}{l}\frac{\sigma}{\infty} \\
\frac{\infty}{N}\end{array}$ & $\underset{\sim}{\stackrel{8}{\sim}}$ & $\stackrel{\stackrel{\vartheta}{a}}{\stackrel{q}{q}}$ & 於 & $\bar{\nabla}$ & $\underset{\stackrel{\infty}{+}}{\stackrel{+}{f}}$ & $\begin{array}{l}\stackrel{0}{0} \\
\stackrel{0}{\sigma}\end{array}$ & $\stackrel{2}{g}$ & $\stackrel{\nabla}{J}$ \\
\hline & z & $\begin{array}{l}\infty \\
\infty \\
\sim\end{array}$ & $\begin{array}{l}\dot{+} \\
\stackrel{\leftrightarrow}{\dot{q}}\end{array}$ & $\begin{array}{l}\stackrel{0}{\infty} \\
\stackrel{人}{ }\end{array}$ & $\begin{array}{l}8 \\
\text { nn } \\
\text { na }\end{array}$ & $\begin{array}{l}\text { + } \\
\text { } \\
\text { d }\end{array}$ & $\stackrel{+}{\stackrel{+}{\alpha}}$ & $\stackrel{\infty}{\infty}$ & $\frac{\mathfrak{N}}{0}$ & $\begin{array}{l}\stackrel{0}{ \pm} \\
\stackrel{+}{=}\end{array}$ & 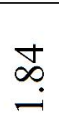 \\
\hline & 3 & $\begin{array}{l}\tilde{n} \\
\infty\end{array}$ & 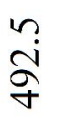 & 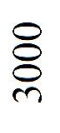 & $\begin{array}{l}8 \\
\stackrel{+}{n} \\
n\end{array}$ & $\underset{\substack{\infty \\
\underset{N}{\infty}}}{\stackrel{p}{2}}$ & $\frac{\mathfrak{\infty}}{\infty}$ & $\underset{n}{\stackrel{v}{n}}$ & ‡ே & $\stackrel{a}{\bar{i}}$ & $\stackrel{+}{\infty}$ \\
\hline \multirow{3}{*}{ 声 } & $\bar{z}$ & $\tilde{\sigma}$ & $\stackrel{\text { va }}{\underline{z}}$ & $\stackrel{0}{0}$ & $\stackrel{8}{\infty}$ & $\bar{a}$ & $\tilde{\sim}$ & $\stackrel{\Upsilon}{-}$ & 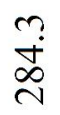 & $\begin{array}{l}\hat{0} \\
\dot{0} \\
0\end{array}$ & $\bar{\xi}$ \\
\hline & z & $\underset{0}{\infty}$ & $\hat{\vartheta}$ & $\frac{0}{n}$ & $\frac{0}{a}$ & $\underset{+}{\infty}$ & $\frac{n}{n}$ & $\stackrel{?}{0}$ & 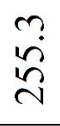 & $\vec{n}$ & $\frac{0}{0}$ \\
\hline & 3 & \begin{tabular}{l}
\multirow{\sigma}{0}{} \\
.
\end{tabular} & $\hat{\stackrel{b}{O}}$ & $\stackrel{\circ}{n}$ & 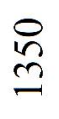 & $\underset{\nabla}{ \pm}$ & $\underset{\stackrel{\infty}{+}}{\stackrel{\infty}{d}}$ & 0 & $\begin{array}{l}0 \\
\tilde{n} \\
\tilde{n}\end{array}$ & $\frac{m}{\sim}$ & $\bar{\xi}$ \\
\hline & & $\frac{T}{2}$ & 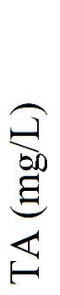 & 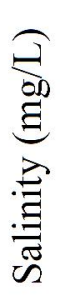 & 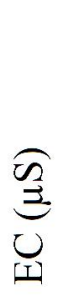 & $\begin{array}{l}\widehat{\vec{\theta}} \\
\stackrel{00}{\Xi} \\
\mathscr{E} \\
\hat{\theta}\end{array}$ & 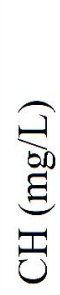 & 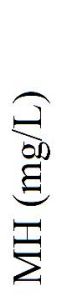 & $\begin{array}{l}\stackrel{\Xi}{D D} \\
\Xi \\
\Xi \\
\Xi\end{array}$ & 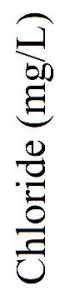 & 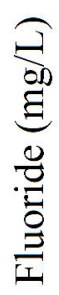 \\
\hline
\end{tabular}


The amount of TDS ranged from 714 to $2870 \mathrm{mg} / \mathrm{L}$ (mean: $1421.0 \mathrm{mg} / \mathrm{L}$ ), 483 to $2840 \mathrm{mg} / \mathrm{L}$ (mean: $1887.5 \mathrm{mg} / \mathrm{L}$ ) and 951 to $2630 \mathrm{mg} / \mathrm{L}$ (mean: $1341.8 \mathrm{mg} /$ L) in the SW, NE and NW segments respectively. The higher TDS content may be deduced due to sea water percolation into the groundwater through small pockets of waterlogged areas is possible as reported earlier (Palanivelu, 2006)

In the present coastal area, the amount of salinity ranged between 750 and $3000 \mathrm{mg} / \mathrm{L}$ (SW), 510 and $2890 \mathrm{mg} / \mathrm{L}$ (NE) and, 1010 and $2700 \mathrm{mg} / \mathrm{L} \mathrm{(NW).}$ The TH of the groundwater samples was registered between 257.6 and 896.1 $\mathrm{mg} / \mathrm{L} ; 255.3$ and $1012 \mathrm{mg} / \mathrm{L} ; 284$ and $910.6 \mathrm{mg} / \mathrm{L}$ in the SW, NE and NW segments with the mean values of $533.5 \mathrm{mg} / \mathrm{L}, 653.1 \mathrm{mg} / \mathrm{L}$ and $465.9 \mathrm{mg} / \mathrm{L}$ respectively. From these values, the 'non carbonate type' nature was observed in all the samples where TH is greater than TA (Chow 1964) in the three segments which is due to the increase in chloride and other ions as witnessed in an earlier study (Subbarao 2006). The groundwater samples were estimated with more $\mathrm{CH}$ with respect to the recomendation of WHO $(75-200 \mathrm{mg} / \mathrm{L})$, which accounts for the existence of calcium rich minerals such as gypsum, limestone, etc. (Murugesan 2004). The chloride content ranged from 212.3 to $1301.9 \mathrm{mg} / \mathrm{L}, 155.7$ to $1174.6 \mathrm{mg} / \mathrm{L}$ and 268.9 to $1096.0 \mathrm{mg} / \mathrm{L}$ in the $\mathrm{SW}, \mathrm{NE}$ and NW segments respectively. The fluoride content varied from the minimum non-detectable level to $1.84 \mathrm{mg} / \mathrm{L}$ and $1.64 \mathrm{mg} / \mathrm{L}$, in the $\mathrm{SW}$ and NW segments respectively whereas the NE segment was recorded between $0.16 \mathrm{mg} / \mathrm{L}$ and $1.84 \mathrm{mg} / \mathrm{L}$.

The ratio of certain chemical parameters such as $\mathrm{Cl} / \mathrm{CO}_{3}{ }^{2-}+\mathrm{HCO}_{3}$-and TA/ TH can be used to assess salt-water intrusion into the coastal aquifers (Rengaraj et al., 1996 and Shanmugam et al., 2006). According to Simpson (1946), the following scale is used to assess the groundwater contaminated by salt-water intrusion (Table 2).

In the study area, the SW and NW segments suffer from salt water intrusion with moderately contaminated aquifers for about $74 \%$ and $75 \%$ respectively. In the NE segment, about $55 \%$ of the groundwater samples were found to be injuriously contaminated and $36 \%$ were moderately contaminated. The NE segment suffers from severe salt water intrusion as compared to the SW and NW segments. According to the groundwater classification(Davis and Dewiest, 1966 \& Freeze and Cherry, 1976) about $87 \%$ of the groundwater samples were found suitable for irrigation and the remaining $(\sim 13 \%)$ were fit for drinking. A similar study related to the pollution of groundwater due to saline water intrusion from the sea in the Manali area was reported by Swaminathan and Narayanan (1994).

The correlation matrix among the water quality parameters is shown in Table 3. The correlation values of EC, TDS, salinity, $\mathrm{CH}$ and TH with chloride is found significant at $1 \%$ level in the SW, NE and NW segments. 


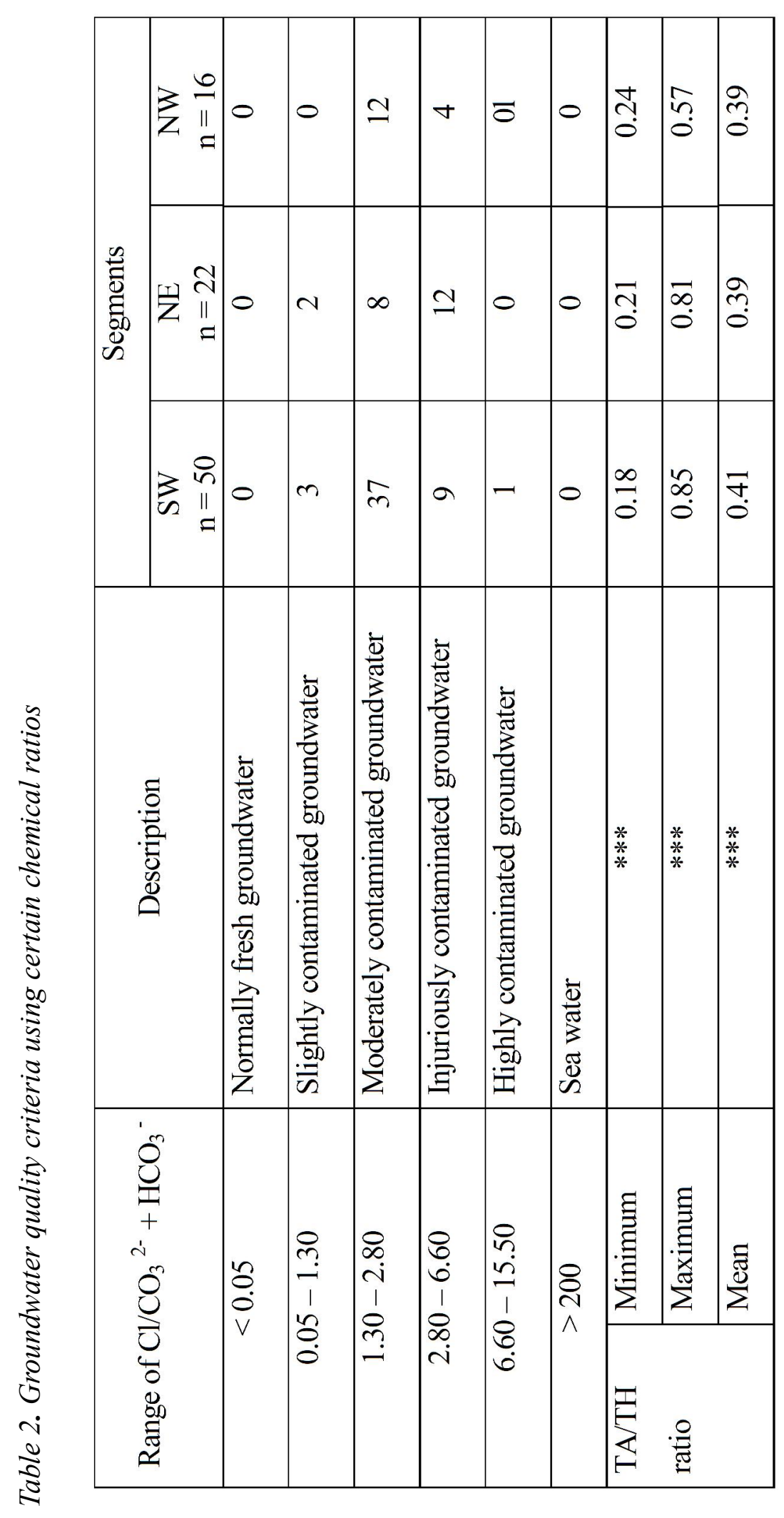




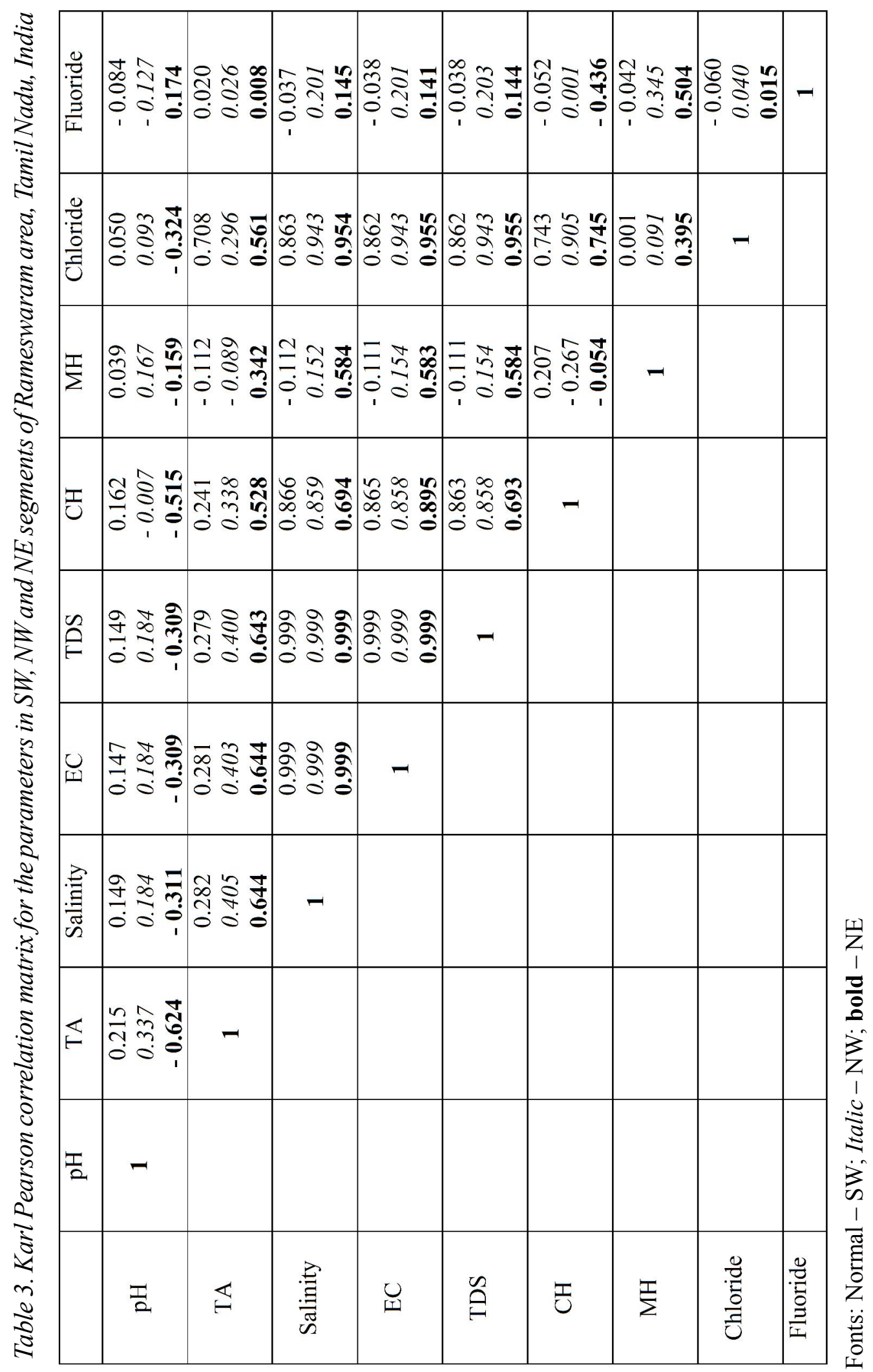


This approves the abundance of calcium rich minerals such as gypsum, limestone ect in thestudy area. The NW segment is remarkably observed with a significant correlation at $5 \%$ level for MH-Salinity and EC-TDS, which evidences the influence of magnesium ions in the quality of groundwater samples. The influence of TA with respect to salinity, EC, TDS, CH and chloride can be accounted from the correlation values 0.644 (TA with EC, salinity and TDS), 0.631 (TA with TH) and 0.561 (TA with chloride) in the NW segment of Rameswaram local area.

The correlation between EC and chloride has been observed with $0.943(\mathrm{SW}), 0.862(\mathrm{NE})$ and $0.955(\mathrm{NW})$ may be attributed to the fact that high conductance reflects the presence of high chloride content in the groundwater samples (Jeyavel Raja et al., 2007). The correlation values of fluoride with calcium in the three segments have been found with no significant influence with respect to each other as reported in the earlier studies (Gupta, 1986; Handa, 1975; Chi man leung, 2005; Paramesha Naik, 2007). But in the NW segment, a significant correlation between fluoride and $\mathrm{MH}(0.504)$ throws some light in the existence of minerals rich in magnesium and fluoride in the study area.

Table 4. Distribution of groundwater samples (\%) within the recomendations of WHO (2006) for drinking water

\begin{tabular}{|l|c|c|c|c|}
\hline Parameters & SW & NE & NW & WHO \\
\hline $\mathrm{pH}$ & 98 & 100 & 100 & $6.5-8.5$ \\
\hline TDS & nil & 14 & 12 & $500 \mathrm{mg} / \mathrm{L}$ \\
\hline TA & 70 & 41 & 81 & $200 \mathrm{mg} / \mathrm{L}$ \\
\hline $\mathrm{CH}$ & nil & nil & nil & $75 \mathrm{mg} / \mathrm{L}$ \\
\hline MH & 82 & 91 & 75 & $30 \mathrm{mg} / \mathrm{L}$ \\
\hline TH & nil & nil & nil & $100 \mathrm{mg} / \mathrm{L}$ \\
\hline Chloride & nil & 5 & nil & $200 \mathrm{mg} / \mathrm{L}$ \\
\hline Fluoride & 96 & 86 & 94 & $1.5 \mathrm{mg} / \mathrm{L}$ \\
\hline
\end{tabular}

\section{Potable status of groundwater samples}

The distribution of groundwater samples within the recomendations of WHO (2006) is shown in Table 4. The value of $\mathrm{pH}$ in most of the samples was found within the recomended limit of WHO. The TDS content in $14 \%$ and 
$12 \%$ of groundwater samples in the NE and NW segments respectively was found below the WHO limit. The NE segment was registered with less percentage $(41 \%)$ of water samples within the recomended limit of TA as compared to the other two segments. In the $\mathrm{CH}$ and $\mathrm{TH}$ contents, no sample was found within the WHO recomended limit in all the three segments. Most of the samples were found within the permissible limit of fluoride in all the segments.

\section{Water Quality Iindex and Langelier Saturation Index}

Water quality index is a suitable tool for deciding the suitability of groundwater for drinking purposes. In the present study area, the NW segment was dominated with about $44 \%$ under Excellent category $(\mathrm{WQI}<25)$ whereas the NE and SW segments dominated with $54 \%$ and $46 \%$ under Good category $(\mathrm{WQI}=26-50)$. The groundwater samples under Poor category $(\mathrm{WQI}=51-$ 75) were accounted for about $14 \%, 18 \%$ and $25 \%$ in the SW, NE and NW segments respectively. Less than $15 \%$ and $5 \%$ of the samples were observed under Very Poor (WQI $=76-100)$ and Unfit (WQI > 100) categories respectively in the three segments.

The LSI values of the groundwater samples infer the nature to deposit more $\mathrm{CaCO}_{3}$ which enhances the scale forming tendency of the groundwater samples. Majority of the samples found to have positive LSI values in all the three segments.

\section{Principal Component Analysis}

PCA was conducted to characterize the linear correlations. The loadings of the variables for each of the PC are obtained. The first principal component is influenced by each original variable. Five principal components were obtained and the PCA suggests that the first dimension of the ordination is by far the most important as it has high eigen values of 2.642, 3.179 and 3.462 and accounts for a large proportion of $37.74 \%, 45.41 \%$ and $49.46 \%$ in the SW, NE and NW segments respectively. The first three PCs in the SW and NE segments account for about $71 \%$ and $81 \%$ of the experimental variance. NW segment registers about $76 \%$ of the experimental variance for the first two PCs. The factor analysis is done for the groundwater samples of the study area and represented in the Table 5. Each variable has high communality that shows variation in common with others and thus clarified for its inclusion in the analysis. In order to make the interpretation easier, varimax rotation is carried out to distinguish the PCs which come under same range of loadings. 


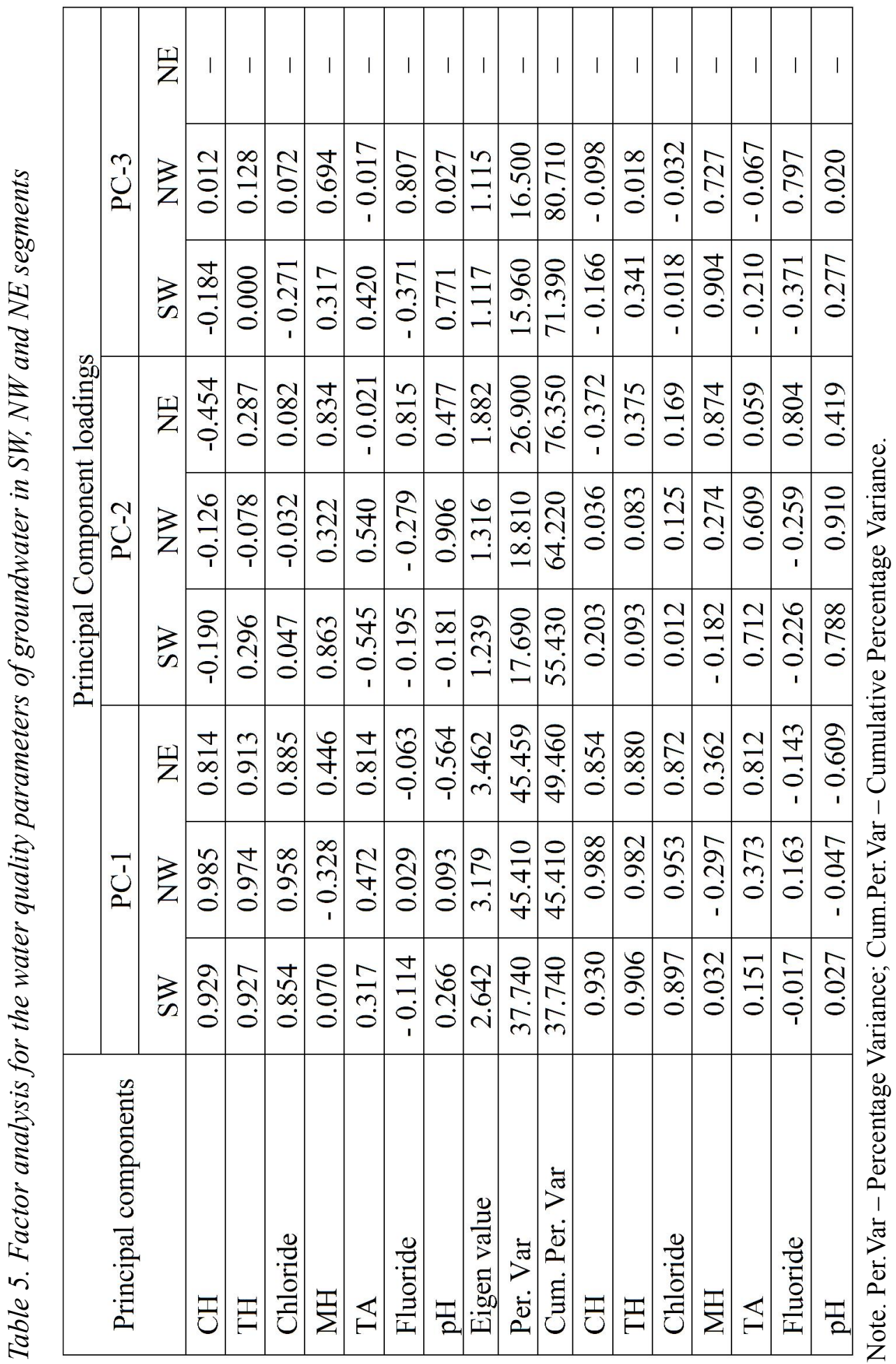


Most significant variables in the components represented by loadings higher than 0.6, are taken into consideration for the interpretation (Mahloch,1974). An interpretation of the rotated three principal components was made by examining the component loadings noting the relationship to the original variables for the samples in the SW and NE segments. The first principal component accounts for about $38 \%$ and $42 \%$ of total experimental variance in the SW and NE segments respectively. The first principal component in the SW and NE segments registers high loadings for $\mathrm{CH}$ (0.929 and 0.985), TH (0.927 and 0.974) and chloride (0.854 and 0.958).

In the NW segment, the first principal component was observed with a total experimental variance of $49 \%$ and high loadings for $\mathrm{CH}(0.814), \mathrm{TH}$ (0.913), chloride (0.885) and TA (0.814). In the second PC, high loadings of $\mathrm{MH}(0.863)$ in the SW segment, TA(0.540) in the NE segment and MH (0.706) and $\mathrm{F}(0.815)$ in the NW segment reflected the existence of minerals associated with carbonates, bicarbonates and magnesium. The concentration of TDS, TA, $\mathrm{CH}, \mathrm{Cl}$ and $\mathrm{F}$ has been found higher in the NE segment as compared to the other remaining two segments whereas heavy load of magnesium has been observed in the NW segment of local Rameswaram area.

\section{Management plan}

A proper management plan needs to be focused for the betterment of peoples' healthy and hygienic life.

1. Potable water is becoming scarce among the populace of the study area which needs immediate attention by way of treatment techniques such as desalination and water softening.

2. As the study area is a symbol of National Integration being visited by people from all parts of the world, a proper land developmental technique such as improved sub-surface drainage should also be adopted to improve the water quality.

3. Erection of a sewage water recycling plant is inevitable in order to recharge the underground water by constructing a battery of injection wells.

4. People of the area need to be educated with the problems and endemic diseases caused by polluted water and advised to make conjunctive and consumptive use of groundwater.

\section{Conclusion}

The groundwater samples of the present coastal area have been found with more salinity, TDS, $\mathrm{CH}$, TA and chloride in majority of the samples beyond the drinking level standards of WHO. Non-carbonate hardness in all the samples has witnessed the existence of greater input of chloride especially after 
monsoon. Salt-water intrusion in the SW and NW segments causing moderate contamination of the groundwater samples was observed. The domination of scale forming tendency has been elucidated through histograms of LSI values in all the three segments. The principal component analysis for the SW, NE and NW segments substantiates the dissolution of heavy inorganic load especially associated with calcium.

As the aquifers are enriched mainly with hardness imparting calcium species, treatment techniques such as water softening, desalination may solve the existing water quality parametric complications. As the scarcity of potable water gets increasing, the Government and Public should work hand in hand for an integrated management by targeting towards furnishing water to all on a sustainable basis.

\section{References}

APHA (2005). Standard Methods for Examination of Water and Wastewater, $21^{\text {st }}$ edn., Washington DC, American Public Health Association.

Brown E., Skougstad M.W., Fishman M.J. (1974). Method for collection and analysis of Water sample for Dissolved Minerals and Gases, US Department of interior, book No.5

Chi-man leung, Jiu J.Jiao, John Malpas, Wing-Tat Chan, Yan-xin Wang (2005) // Environ Geol. 48. P. 480 - 495.

Chow V.T. (1964). Handbook of applied hydrology. New York, McGraw-Hill. Datta N.C. (2007) // J. Indian Water Works Assoc. (april - june).

Davis S.N., DeWiest R.J.(1966). Hydrogeology. New York, Wiley.

Eilers R. G., Eilers W.D., Fitzgerald M.M.(1997) // Hydrogeol. J. 5.P. 68 - 79.

Freeze R.A., Cherry J.A.(1979). Groundwater. New Jersey, Prentice-Hall.

Goel P.K. (2000) Water pollution - Causes, Effects and Control, New Delhi, New Age Int. (P) Ltd.

Gupta S., Banerjee S., Saha R., Datta J.K., Mondal N. (2006) // Fluoride. 39(4). P. $318-320$.

Handa B. K.(1995) // Groundwater. 13. P. $275-281$.

Jeyavel Raja Kumar T., Kumar R.S., Singarasubramaniyan S.R., Manoharan $K$. (2004) // Eco. Environ. and Cons. 13 (2). P. 265 - 269.

Kaiser H.F. (1958) //Psychometrica. 23. P. 3.

Langeleir W.F. (1946) //J. Amer. Water Works Assoc. 38. P. 169.

Li J.X., Cao S. R. (1994)//Fluoride. 27. P. $125-128$.

Mahloch J.L.(1974). Environ. Eng., Div. Amer. Soc.,Civil Eng.100.No.EE5, P.1119-1132.

Mosoud A.A., Koike K. (2006) //J. Arid Environ. 66. P. 151 - 167.

Murugesan S. (2004) // Environ. and Pollut. Technol. 3(4). P. 495 - 499.

Norusis M.J. SPSS for Windows. 6.1.3. Users Guide, SPSS Inc. Chicago, 1996.

Palanivelu K., Nisha Priya M., Muthamil Selvan A., Usha Natesan (2006)

//Current Sci. 91(5). P. $583-584$. 
Paramesha Naik, Usha Malini, Somashekar R.K. (2007). //Eco. Environ. and Cons. 13 (2). P. $303-305$.

Pozdnyakova L., Zhang R. D.(1999)//Precision Agriculture. 1. P. 153 - 165. Kaufmann R.(2007)//Health Action. 20(2). P. 18 - 19.

Ramachandramoorthy T., Sivasankar V., Subramanian V.(2009)//Environ. Monit Assess. 159. P. $511-520$.

Rengaraj S., Elampooranan T., Elango Ramalingam V.(1996) // Poll. Res. 15. P. $325-328$.

Saleem Romani //Water Digest. Jan - Feb 2007. P. 12 - 28.

Shanmugam P., Neelamani S., Yu-Hwan Ahn, Ligy Philip, Gi-Hoon Hong (2007) //Water Res. Manage. 21(7). P. 1307 - 1316.

Simpson T.R (1946). Salinas barin investigation. Bull. 52. California Division of Water Resources, Sacramento.

Sivasankar V., Ramachandramoorthy T.(2009) //Environ. Monit Assess. 156. P. $307-315$.

Statistical Hand Book (2006). Department of Statistics and Economics, Ramanathapuram District.

Subba Rao N. (2006) //Environ. Geol. 49. P. 413 - 429.

Swaminathan S.S., Naryanan S. (1994). Groundwater quality monitoring in Manali (Tamil Nadu), Report of Public Works Department(Groundwater Wing), Chennai, India.

Tiwari T.N., Mishra M. (1985) // Indian J. Environ. Prot. 5(4). P. 276 - 279.

Ward P.R., Fillery I.R.P., Maharaj E.A., Dunin F.X. (2003) // Plant and Soil. 257. P. $305-319$.

World Health Organisation (2006). Guidelines for Drinking Water Quality (vol. 2). Health Criteria and other supporting information ( $2^{\text {nd }}$ ed.). Geneva. P. $231-233$.

Received 15.04.2011 